DOI: $10.54631 /$ VS.2021.S-6-10

\title{
WHICH VIETNAM IS UNDER NEW FRENCH RESEARCH TODAY? Benoît de Tréglodé
}

In the 1960s and 1970s, the humanities and social sciences were largely at the service of an idealised quest aiming at the socialist revolution. In France, academic research on communism in the Third World countries was fuelled by anti-colonial guilt. The change came from within in the early 1980s, when the exodus of Viet Kieu and the security orientation of the country's reunification distracted some of the intellectuals who were "fellow travellers" (compagnons de route) from the triumphant narratives about this country in the 1960s and 1970s. In 1983, a book vividly presented the contradictions of this period experienced by specialists of Vietnam in France with regard to their present or past commitments with Vietnamese communist regime. The historian Georges Boudarel mentioned: "This publication is not a crusade, without complexes or taboos. It intends to place itself under the sign of mutual respect, plurality of points of view, coexistence and tolerance of opinions. These are not exalting slogans, nor are they flags to mount an assault. These terms lack panache and hardly rattle in the wind. But they sum up the hard experience of men. We will not hesitate to make them ours." [Boudarel 1983: 11].

When Vietnam reopened to Western scholars, French researchers were encouraged to go back by the revival of an office of the Ecole française d'Extrême-Orient (EFEO) in June 1993, after 34 years of absence. A new generation of researchers, I was one of them, claimed the need to do field research in Vietnam, turning its back on past works that was often considered too politicised. In the last thirty years, while a reversal of perspective would have been useful in the study of contemporary upheavals in Vietnamese society after the Doi Moi, academic work devoted to Vietnam after the wars for independence has paradoxically become scarce in France. Without war or ideology, the country attracts considerably less attention. It must be admitted that this difficulty in grasping post-conflict Vietnam, a country that is as geopolitically audacious as it is economically active, is only echoed in the slow disappearance of France in its culture.

For the past twenty years, the generalization of transnational approaches in the academic field has been a common practice in France. However, in the case of historiography on Vietnam, with the exception of a handful of largely Anglo-Saxon works, this methodological bias has been slow to take hold. Writing the history of Vietnam invites us to place at the heart of the analysis the question of trajectories and phenomena that evoke the migration of men, the networks of Vietnamese revolutionaries, and the transfers of goods and ideas. This should not be limited to communism alone but should include, in a general way, all Western and then Asian values and ways of thinking, as well as climate change, pandemics, technological progress and the development of trade. In many ways, this perspective illustrates the affirmation of a country that is more in control of its destiny and that has facilitated the emergence, over the past thirty years, of a host of new political, religious, economic, and social actors, whose presence determines the dynamism and in-depth renewal of the society.

For decades, the choice of a research theme in the field of Vietnamese studies has represented an ideological issue in Western countries. There were subjects that could be studied among scholars (communism, neo-Confucianism, culinary arts, architecture, oral literature, popular cultures and the 
village world, etc.), and others that were better avoided (non-communist nationalist movements, religious "sects" and revivals, security actors, ethnic politics, etc.). With the opening of Vietnam, French research on the country had to readapt. The turn towards social history and village studies was, however, not unrelated to the encouragement of the Vietnamese scientific community. At the time, the Academy of Social Sciences of Vietnam made the study of the cultural origins of the country a new scientific priority. A large part of Western research has embraced these orientations. Directing the work of its researchers, and of foreign academics who were "friends of Vietnam", towards the study of rites and customs of thousand-year-old traditions was, for the Vietnamese, tantamount to confirming the West in its conception of political openness. Villages became reservoirs of traditions of a country isolated from the flows of the society that surrounded it. The return to this unchanging past relegated to the background the "new society" of socialist inspiration that was no longer appropriate. Studying the history of communism hung Vietnam up on a past that its present sought if not to neglect - at least to put in the background - what was tradition (truyền thống dân tộc Việt Nam) and popular culture (văn họ dân gian). So, this angle of study could only be commendable because, to put it simply, it brought back an idealized construct. But the "traditional village" of today in Vietnam, like that of the "new communist man" of previous decades, is nevertheless still very much a part of the same collective fantasy and political construction.

It is definitely outside these (maybe already old-fashioned) fixed categories that the question of the study of contemporary Vietnam will be asked by the new generation of French $\mathrm{PhD}$ researchers gathered in this issue of the Russian Journal of Vietnamese Studies. In recent years, a new history of Vietnam has emerged outside its borders thanks to the study of Vietnamese language sources, Russian and Chinese, and thanks to the use of archival collections from several countries of the former socialist bloc (East Germany, Hungary, Czech Republic, Rumania and Poland in particular). Vietnamese leaders sometimes fear heterodox historical re-readings that contradict the linearity of an official history that grants the regime a natural place in the genealogy of their power in the face of a changing world. This political strategy can be seen when one observes the behaviour of the Vietnamese elite over the centuries, marked by constant internal divisions, between the Trinh, the Mac, and the Nguyen (from the sixteenth to the eighteenth centuries), between colonialists and patriots, nationalists and communists from 1854 to 1954, between the supporters of the southern regime and those of the DRV from 1954 to 1975. Given the complexity of these entanglements, we have sometimes confined ourselves to the title of the names alone (Nationalist Vietnam versus Communist Vietnam, etc.). The risk is not for the Vietnamese elite to question its communist identity in the twenty first century but above all to weaken the historical legitimacy of its conquest of power. If the Vietnamese do not expect a strictly ideological position from the Communist Party, they are on the other hand looking for a protector in the turmoil of their contemporary history, in order to manage the relations between the members of the community. By doing so, and this is a reality that is sometimes difficult to hear in France, the older generation, the one that took up arms to liberate itself, is today pleased with the transformation of society, and follows in the footsteps of a large part of the youth, dreaming of material success, and showing little interest in ideological debates.

In this perspective, the works of young French researchers presented in this issue fall into three main areas. The first objective is to write an Asian/Vietnamese history of Vietnam, i.e., a history that relies as much as possible on vernacular sources from a society that was neither thought nor produced by external powers, successively France, the Soviet Union, China, or expressed today almost exclusively in Anglo-Saxon research. The second objective is to lay the groundwork for a history or an understanding of the Vietnamese society that is both global and that takes into account 
the diversity of its actors (state and sub-state, political, cultural and religious) without neglecting the transnational dimension of its political networks and the geopolitical constraints specific to each era and country. The third objective is to propose a transdisciplinary reading that takes into account the latest historiographic advances while remaining empirical and in touch with the daily reality of the country. From a methodological point of view, the young authors of this issue all have an intimate knowledge of their research object, which necessarily includes a mastery of the Vietnamese language and time in their research field in Vietnam. This view from the inside allows us to better grasp the social links and the relationships of belonging experienced by the internal actors (State, groups, individuals) through their inscription in a cultural space. How were they articulated to the imaginary space of the nation? An important part of the studies in this issue deals with these traces, these "identity markers", within Vietnam with the modernization of its economic model, the transformation of the rural world, the urban transition, the religious beliefs, and the new data of its civil society or the ecological and environmental transition in its territories.

The first part of this issue deals with domestic and foreign policy. Antoine Lê's contribution sheds light on the strategies of the Vietnamese communist authorities in the run-up to their victory in 1975. The young historian examined the transition of power in Saigon after April 30, 1975 from the Republic of Vietnam (RVN) to the combined Vietnamese revolutionary forces by studying the Military Administration Committee for the City of Saigon - Gia Dinh. His paper provides an overview of both the position of the UBQQ in the state and party apparatus of South Vietnam's revolutionary movement as it was in 1975, as well as an overview of the plan that revolutionary leaders had to take over Saigon in final stages of the Vietnam War in 1975. The second contribution written by Thi Thanh Phuong Nguyen-Pochan, PhD from the University of Paris 8 and lecturer at the Catholic University of the West, studies the same paradox through the state management of social media and online public opinion in Vietnam. The "enemy" is also within and not only at its borders. On the one hand, the study examines a combination of measures implemented since 1997 by the government and three ministries in charge of Internet management (Information and Communication, Public Security and Defence). On the other hand, her study looks into the fragility and malleability of control mechanisms in the current context.

The contributions on the history of Vietnam and the centrality of Vietnamese communist power since the 1950s allow for a better understanding of current societal issues linked to the reemergence of Vietnamese territory over the last three decades in the context of a reinvigorated economic openness and its repositioning in its Asian environment. Johann Grémont, $\mathrm{PhD}$ researcher from the University of Paris and author of his own book deals with Vietnamese foreign policy within a historical approach by analysing the maintenance of law and order in the China-Vietnam borderlands during the French colonial period (1896-1940) [Grémont 2018]. This article aims to analyse how the French colonial administration tried to keep order on the Tonkin border. It explains how this diverse borderland area with a harsh climate and a multi-ethnic population coveted many issues, giving birth to the challenges of law and order on border. Then, Jean-Philippe Eglinger, an INALCO's economist, is interested in how the Government and the Communist Party are looking at the private sector and its contribution to the economy and how they officially intend to use it to contribute to the country prosperity. The author analyses how the private sector in Vietnam is positioning itself compared to the public sector and examines how the State through the foreign investment sectors is actually piloting the private economy.

In the following paper, Clara Jullien (Université Paris 1 - Panthéon Sorbonne) analyzes the trajectories and practices of individuals, in migration decision-making, in terms of risk management 
and space appropriation. From an urban geography perspective, she chooses to focus on the final step of migration trajectories, pushing the doors of the renting rooms of Go Vap districts. The conditions and the time of her research have allowed her to access to empirical elements on how this population experienced the first waves of the pandemic and its impact on the Vietnamese economy. Through life-story interviews, this research studies how multicultural so-called "rural migrants" transit from the village to the city, from the agricultural sector to the urban job market. Then Marion Reinosa (University of Paris) in her paper entitled "Building South Vietnamese Delta Settlements in the Whirlwind of Climate Change", argues for an alternative paradigm in which cities promote and integrate local communities' building knowledge to enable architectural and urban forms to play a leading role in the resilience of Vietnamese deltaic cities and mitigate mankind's impact on the environment. Leaving South Vietnam to the central part of the country, Sunny Le Galloudec (University Le Havre - Normandy) works on the French Concession of Tourane between 1884 and 1889. The main point of his paper is to show that a new form of territorial colonial rule was introduced in Indochina, for and from Tourane/Đà Nẵng first, and then in other key points of the Indochinese Union, which was still under consolidation. That is what he calls "micro-colonies". To do so, he examines the political context during which the French concession of Tourane/Đà Nẵng was conceived, the work and conclusions given by the commission in charge of studying its borders and jurisdiction, and the steps taken by the colonial administration in order to obtain this new conceded territory. Finally, among young French scholars, there is quite a lot of work in the field of religious issues with anthropological or historical approaches. The same pattern is found for other young researchers working in other fields throughout South East Asia. Camille Senepin (a doctorant student at EHESS - Paris), offers in her paper on the creation of Đạo Mẫu cult an analysis of the dynamics of the cult of the Four Palaces outside of Hanoi. Camille Senepin is currently doing her fieldwork in a specific locality, the religious place of Phu Day, in Nam Dinh province. She shows in her work the importance of the locality within this cult, and how specific places can create singular discourses about the deities, the mediums and the followers. In her research, Camille Senepin explains how the participants of the contemporary Đạo Mẫu cult are creating their own tradition, although influenced by the heritagization of the cult and the successive government directives. And finally, in the last chapter of our issue, Guilhem Cousin-Thorez, PhD candidate at IrAsia (Aix-en Provence- Marseille) devoted his research to the Buddhist community's situation in Vietnam prior to the crises of the 1960's. Focusing on the most active monks and laymen, it addresses a decade of their religious activities, especially the misknown creation of the first national Buddhist association - the General Buddhist Association of Vietnam.

What characterizes the great diversity of these nine papers can be summarized by a strong desire to decentralize territorially their reading of Vietnam. While the previous generation of researchers was mainly focused on Hanoi or the northern part of the country - and continued to have an almost obsessive regard for the central state, I confess, - the new one embraces the whole territory, and the most diverse stakeholders. It is probably easier to work in the provinces than it was then. Anthropologists, historians, sociologists, economists and political scientists nowadays make no secret of their interest in different actors active at the margins of the state apparatus. Although this level was for a long time the main subject of study in Western research, this is no longer a scientific reality. It is as if this process of depoliticization of French research on Vietnam continues to progress, influencing even the territories where young researchers are assigned. While the place and role of the Vietnamese Communist Party in society has long irrigated French research on this country, the revival of social history in the 1990s - which was certainly not without ideological ulterior motives - and the 
more recent 'Asianisation' of Vietnamese society alongside with opening up of the country is pushing the young French researchers towards new territories and new actors, "next to the State". Unsurprisingly, all of these works are based on a "Vietnamisation" of the points of view, a reading of the country's transformation paths from the inside. This special issue, in sum, offers a glimpse in areas of the young Vietnamese studies in France that are rarely presented. It was with great humility and pleasure that I accompanied the preparation of this special issue. I hope all will enjoy reading it.

\section{References}

Boudarel G. (1983). The Bureaucracy in Vietnam. Paris: L'Harmattan.

Grémont J. (2018). Maintenir l'ordre aux confins de l'Empire. Pirates, trafiquants et rebelles entre Chine et Viêt Nam (1895-1940) [Maintaining Order on the Borders of the Empire. Pirates, Traffickers and Rebels Between China and Vietnam (1895-1940)]. Paris: Maisonneuve \& Larose.

\section{Author:}

Benoît de Tréglodé, Director of the Africa - Asia - Middle East Department, Institute for Strategic Research (Ecole Militaire, Paris) (IRSEM), Researcher, South-East Asia Center (CASE), School for Advanced Studies in the Social Sciences (EHESS). Former Director of the Research Institute on Contemporary Southeast Asia (IRASEC) in Bangkok (Thailand). Member of the editorial committee of Les champs de Mars (revue d'études sur la guerre et la paix), Sciences Po, Paris / IRSEM.
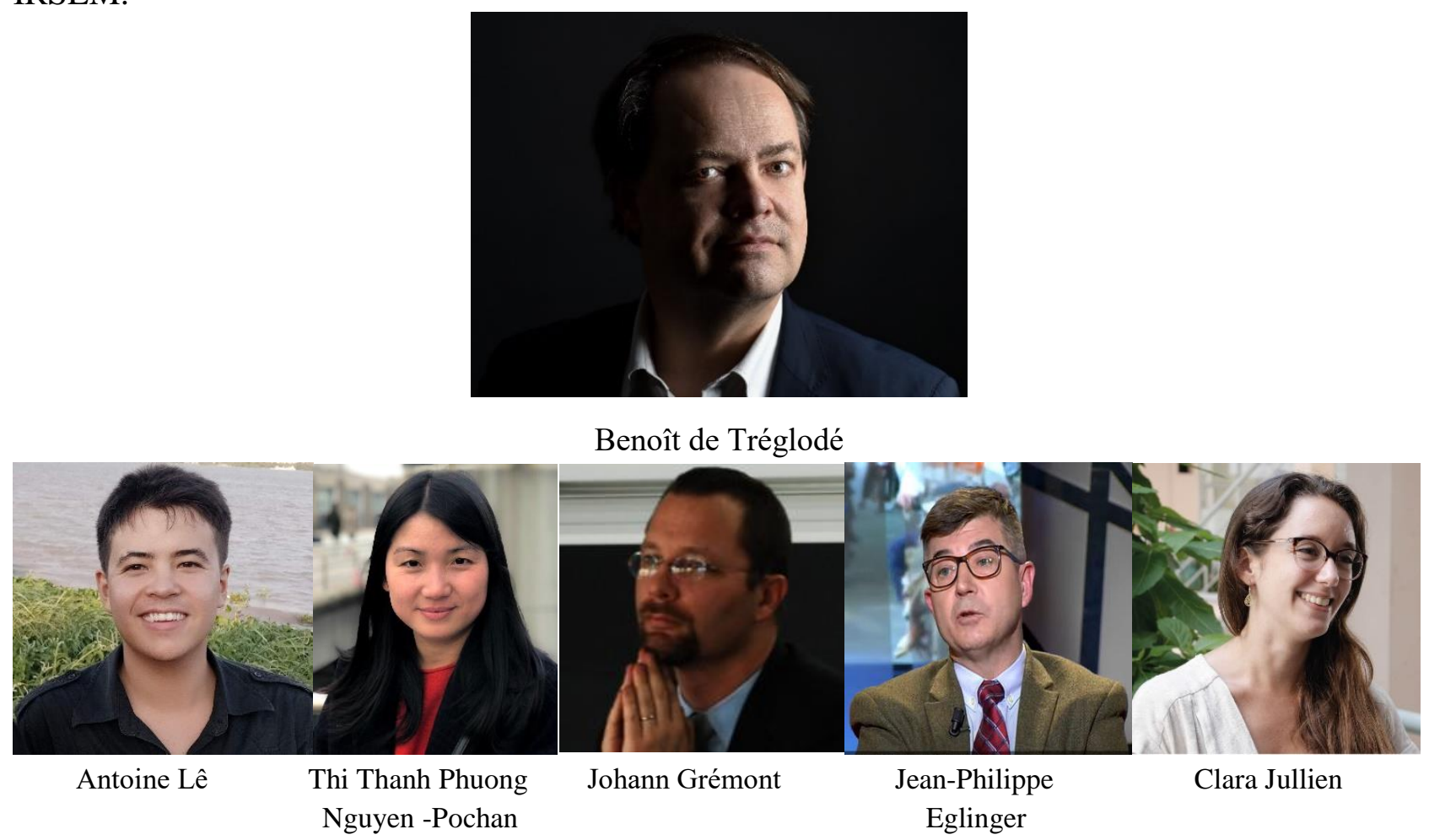

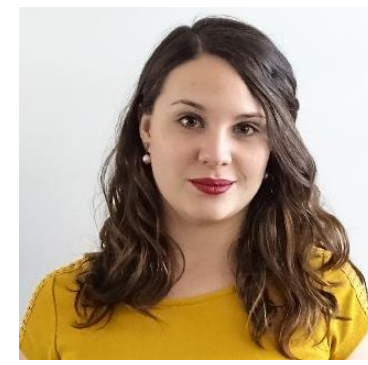

Marion Reinosa

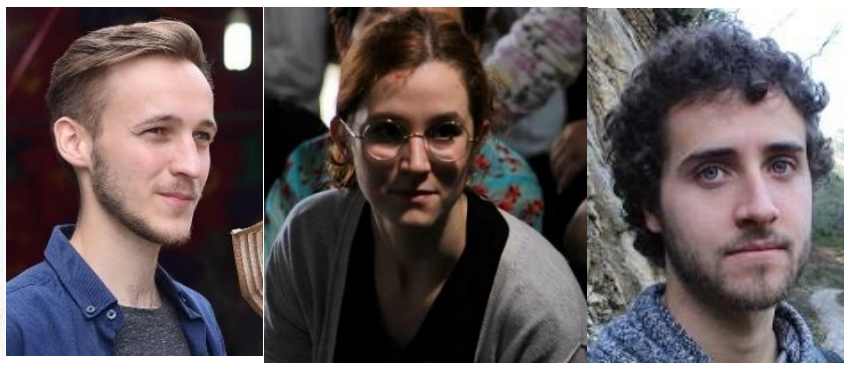

Camille Senepin

Sunny Le Galloudec
Guilhem

Cousin -Thorez 